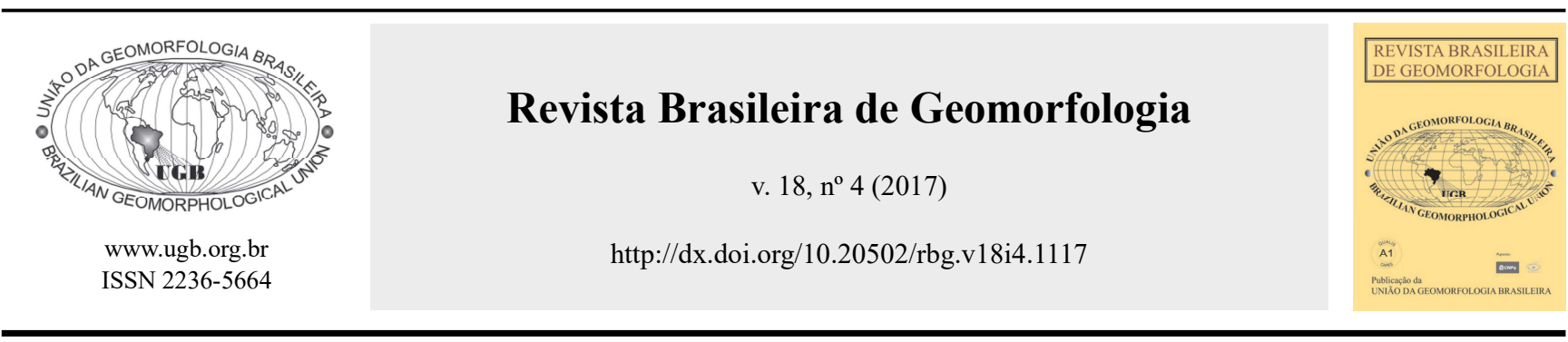

\title{
MULTI-CRITERIA ANALYSIS APPLIED TO LANDSLIDE SUSCEPTIBILITY MAPPING
}

\section{ANÁLISE MULTI-CRITÉRIO APLICADA AO MAPEAMENTO DA SUSCETIBILIDADE A ESCORREGAMENTOS}

\author{
Mariana Madruga de Brito \\ Department of Geography, University of Bonn \\ Meckenheimer Allee, 172, Bonn. CEP: 53115. Germany \\ Email:mmdb@outlook.com
}

Eliseu José Weber

Centro de Ecologia, Universidade Federal do Rio Grande do Sul Av. Bento Gonçalves, 9500, Porto Alegre, Rio Grande do Sul. CEP: 91540-000. Brazil Email:eweber@portoweb.com

Luiz Carlos Pinto da Silva Filho

Grupo de Gestão de Riscos de Desastres, Universidade Federal do Rio Grande do Sul Av. Osvaldo Aranha, 99, Porto Alegre, Rio Grande do Sul. CEP: 90035-190. Brazil

Email: lcarlos66@gmail.com

\begin{tabular}{l} 
Informações sobre o Artigo \\
\hline Recebido (Received): \\
15/06/2016 \\
Aceito (Accepted): \\
$01 / 07 / 2017$
\end{tabular}

\section{Keywords:}

Porto Alegre; Analytical Hierarch Process; AHP; landslides.

\section{Palavras-chave:}

Porto Alegre; Processo Analítico Hierárquico; AHP; escorregamentos.

\begin{abstract}
:
This paper presents the application of a multi-criteria analysis (MCA) tool for landslide susceptibility assessment in Porto Alegre municipality, southern Brazil. A knowledge driven approach was used, aiming to ensure an optimal use of the available information. The landslide conditioning factors considered were slope, lithology, flow accumulation and distance from lineaments. Standardization of these factors was done through fuzzy membership functions, and evaluation of their relative importance for landslide predisposition was supported by the analytic hierarchy process (AHP), based on local expert knowledge. Finally, factors were integrated in a GIS environment using the weighted linear combination (WLC) method. For validation, an inventory, including 107 landslide points recorded between 2007 and 2013 was used. Results indicated that $8.2 \%\left(39.40 \mathrm{~km}^{2}\right)$ of the study area are highly and very highly susceptible to landslides. An overall accuracy of $95 \%$ was found, with an area under the receiver operating characteristic (ROC) curve of 0.960 . Therefore, the resulting map can be regarded as useful for monitoring landslide-prone areas. Based on the findings, it is concluded that the proposed method is effective for susceptibility assessment since it yielded meaningful results and does not require extensive input data.
\end{abstract}




\section{Resumo:}

Este estudo apresenta a aplicação de uma ferramenta de análise multi-critério para mapear a suscetibilidade a escorregamentos no município de Porto Alegre, sul do Brasil. Uma abordagem guiada pelo conhecimento de especialistas foi utilizada, com o intuito de otimizar a utilização das informações disponíveis. Os fatores condicionantes dos escorregamentos considerados foram declividade, litologia, acúmulo defluxo e distância de lineamentos. A padronização desses fatores foi realizada por meio da aplicação de funções fuzzy e a importância relativa de cada um na predisposição do terreno a escorregamentos foi estabelecida com o apoio da técnica AHP (Analytic Hierarchy Process), com base no conhecimento de especialistas locais. Por fim, a integração dos fatores em ambiente SIG se deu por meio do método denominado Combinação Linear Ponderada (WLC). Para validar os resultados, utilizou-se um mapa inventário contendo 107 cicatrizes de escorregamentos, registradas entre 2007 e 2013. Os resultados indicam que $8,2 \%\left(39,38 \mathrm{~km}^{2}\right)$ da área de estudo possui uma suscetibilidade alta e muito alta a escorregamentos. A validação dos resultados obteve uma exatidão geral de $95 \%$, com uma área abaixo da curva ROC (Receiver Operating Characteristic) de 0,960. Portanto, o mapa obtido pode ser considerado útil para monitorar as áreas propensas a esses processos. Com base nos resultados, conclui-se que o método proposto é eficaz para a avaliação da suscetibilidade, uma vez que os resultados obtidos são robustos e que não foi necessária uma quantidade extensa de dados de entrada.

\section{Introduction}

The accelerated urbanization in developing countries without proper spatial planning has often led to the occupation of unsuitable or hazardous areas, such as hilly slopes and unstable ground (Di Martire et al. 2012). The increase of population density in these places, without considering the fragility of the environment, exposes people and buildings to landslide events, which can cause economic losses, social and environmental impacts and, in extreme cases, loss of human lives (Fell et al. 2008; Zhu et al. 2014).

In Brazil, due to their frequency and damage, landslides represent the second most destructive natural hazard. Between 1991 and 2012, 2,868 fatalities occurred (IPT 2014) and approximately 5.87 million people were affected (i.e. injured, homeless, displaced, evacuated or requiring immediate assistance) by these processes (UFSC and CEPED, 2014). Apart from the loss of lives, landslides also result in great economic losses. As an example, the mass movements that occurred in 2011 in the mountainous area of Rio de Janeiro State caused more than US\$ 2.8 billion in damage (World Bank 2012).

In order to mitigate these impacts, the assessment of landslide susceptibility is particularly valuable, given that it may help to select appropriate preventive and corrective risk reduction measures (Liu and Wu, 2008). The effective use of these studies provides an indispensable instrument for landslide risk management, not only for identifying areas where detailed studies are needed, but also for assisting decision makers to elaborate land-use planning policies.
A variety of approaches has been proposed to assess landslide susceptibility at different observation scales. They can be grouped basically into three types: (1) deterministic (e.g. classical slope stability theory and safety factor analysis), (2) statistical (e.g. bivariate and multivariate analysis) and (3) heuristic (e.g. map combination and field geomorphological analysis) (Guzzetti et al. 1999; Fell et al. 2008). Deterministic approaches allow computing safety factors and normally provide accurate results. However, such investigations are usually cost-intensive and time-consuming due to the amount of geotechnical and groundwater data needed and, thus, are more suitable for small and site-specific studies (Aleotti and Chowdhury 1999; Barredo et al. 2000; Ayalew and Yamagishi 2005). Likewise, statistical methods demand detailed landslide inventories (Soeters and Van Westen 1996), which are still scarce in developing countries. On the other hand, heuristic approaches based on the combination of maps, normally do not require extensive input data and are relatively straightforward to apply and update. The major drawback is the subjectivity since the results are based entirely on the judgment of the person carrying out the study (Guzzetti et al. 1999; Aleotti and Chowdhury 1999; Barredo et al. 2000). Nevertheless, as pointed by Van Westen (2000), subjectivity is not necessarily problematic when it is based on expert knowledge. Therefore, due to its capability to handle scarcity of data, heuristic approaches based on multi-criteria analysis (MCA) have been widely applied for assessing landslide-prone areas in recent years (e.g. Ruff and Czurda 2008; Hasekioğulları and Ercanoglu 2012; Günther et al. 2012, 2014; Feizizadeh et al. 2013, 2014; Dragićević et al. 2015). 
In Brazil, several governmental institutions and scientific groups have suggested guidelines for assessing landslide susceptibility, using mainly geomorphological analyses (e.g. Macedo et al. 2013; Pascarelli et al. 2013) as well as deterministic approaches (e.g. Listo and Vieira 2012; Michel et al. 2014; Nery and Vieira 2015). Such methods are typically applied in areas smaller than $20 \mathrm{~km}^{2}$ due to the large volume of field data and/or laboratory tests required and, therefore, are more suitable for local-scale analysis. Nevertheless, available data could be employed to perform preliminary assessments in entire municipalities, using GIS-based MCA tools. This makes the mapping process and its updates flexible and, therefore, may help to optimize the allocation of limited financial resources. Once preliminary landslide maps are concluded, detailed mappings efforts can be better planned, giving priority to critical areas (Carrara and Guzzetti 1999; Guzzetti et al. 1999). Despite its advantages, GIS-based MCA approaches for susceptibility assessment are rarely applied in Brazil, with limited research available (e.g. Bortoloti et al. 2015). Another issue is that the existing MCA approaches are most commonly applied to non-urbanized areas where only natural factors dominate (e.g. Komac 2006; Feizizadeh et al. 2014).

Therefore, this study aims to apply a GIS-based MCA approach for landslide susceptibility assessment in a highly urbanized area, taking into account the data availability limitations and uncertainties. The methodology seeks to make use of existing information and local expert knowledge, aiming to build a flexible and fairly inexpensive approach. For this purpose, techniques such as fuzzy logic, analytical hierarchy process (AHP), and weighted linear combination (WLC) were applied, and the results were validated through the analysis of receiver operating characteristics (ROC) curves. This approach was tested in the Porto Alegre municipality, Brazil, where landslides are a recurrent problem. The research outcomes are intended to support local authorities in prioritizing hazard and risk assessments.

\section{Study area}

The study was carried out in the Porto Alegre municipality, Rio Grande do Sul State, southern Brazil. It comprises $476.3 \mathrm{~km}^{2}$ (Figure 1) with an estimated population of 1.480.000 inhabitants (IBGE 2016). The regional climate is classified as humid subtropical (Köppen Cfa class), with a mean annual rainfall of $1,300 \mathrm{~mm}$ and a maximum 24-hour precipitation of $165 \mathrm{~mm}$ (INMET
2014). The geologic basement consists of neoproterozoic granitic rocks, paleoproterozoic gneisses, and dykes, which are crossed by two large faults: the Porto Alegre Suture and the Porto Alegre Transcurrent Shear Zone. These units are partially covered by younger cenozoic sedimentary deposits, such as alluvial and elluvial deposits, terraces and beach ridges (Philipp 2008; Philipp and Campos 2004). Elevations vary from $0 \mathrm{~m}$ near the Guaíba Lake, to $309 \mathrm{~m}$ at the Porto Alegre Ridge, while the slope gradient ranges between $0 \%$ and $745 \%$, with an average of $10 \%$.

Porto Alegre has the highest number of landslide records in Rio Grande do Sul State, counting six fatalities and twelve injuries between 1980 and 2005 (Reckziegel 2007). It was considered in 2011 by the Brazilian Federal Government as a priority for disaster prevention (MI 2013). Thus, there is a growing need for developing landslide susceptibility maps for this area. Shallow and rotational landslides are the most common processes, followed by rock falls, which predominate along fault zones located on the granitic hills of the Porto Alegre Ridge, highly fractured and weathered (Fujimoto 2002; Reckziegel 2012; 2013). As mentioned by Brito et al. (2017), the disordered urban occupation, especially by the construction of improperly cut and fills on steep slopes, the removal of vegetation and the concentration of surface water flow due to improper drainage systems, often triggers these processes (Figure 2).

\section{Material and methods}

The landslide susceptibility assessment was carried out following a knowledge driven GIS-based MCA approach, as summarized in Figure 3. At first, contour lines of a topographic map at 1:1,000 scale (Hasenack et al. 2010), which was produced in 1982, were used to generate a digital elevation model (DEM). A triangulated irregular network (TIN) model was applied, taking into account its advantages to describe areas with complex relief as the study area (Eastman 2009). Boundaries of lithology and lineaments were extracted from a geological map at 1:50,000 scale (Philipp 2008). Then, aiming a compromise between taking advantage from the available data and compensation for differences on cartographic scale, all layers were converted to raster using a grid size of $5 \times 5$ meters. The resulting elevation grid enabled the creation of slope and flow accumulation layers, as the first and second relief derivatives, while distance from lineaments was computed from the respective raster. Geospatial data processing was performed using Idrisi Selva and ArcGIS 10 software 
Brito M. M. et al.

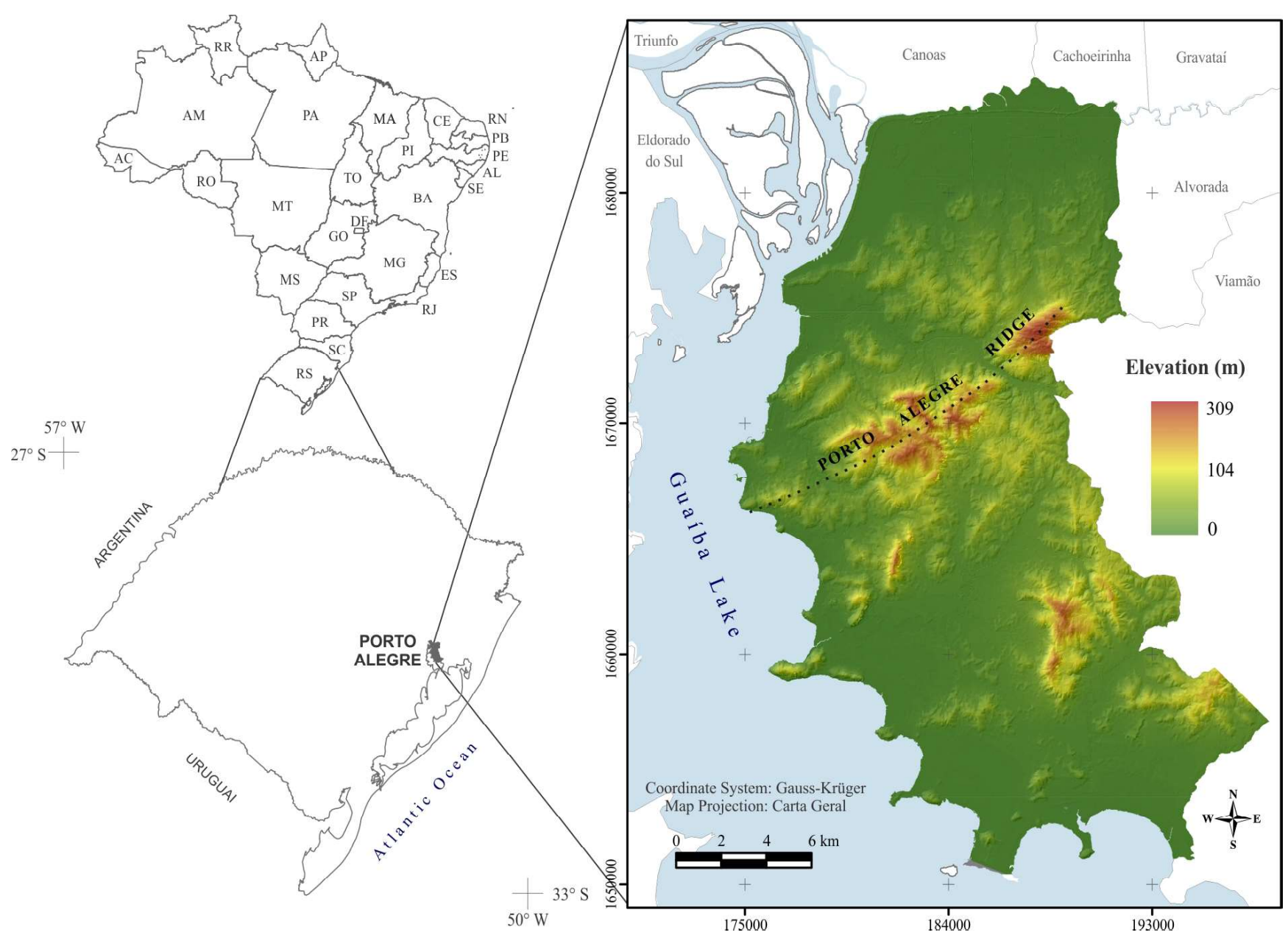

Figure 1 - Location and elevation of the study area, Rio Grande do Sul State, southern Brazil.
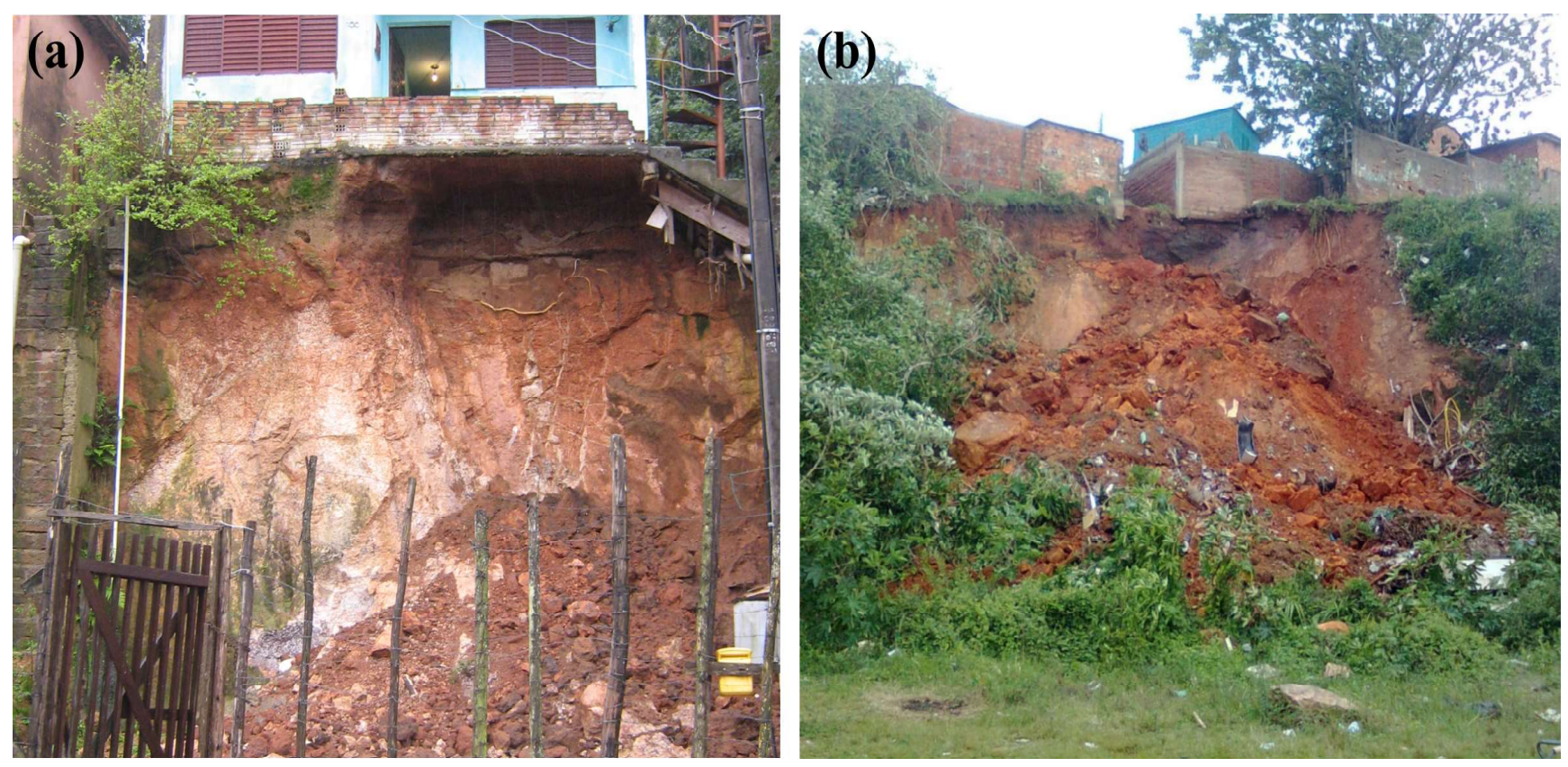

Figure 2 - Human-induced landslides in Porto Alegre: (a) high cut slope in Dallas Street, 2007. (b) natural slope on São Guilherme Street, 2012, where sewage and debris were thrown directly into the hillside. Source: images provided by PAR (Programa de Areas de Risco de Porto Alegre - SMAM). 


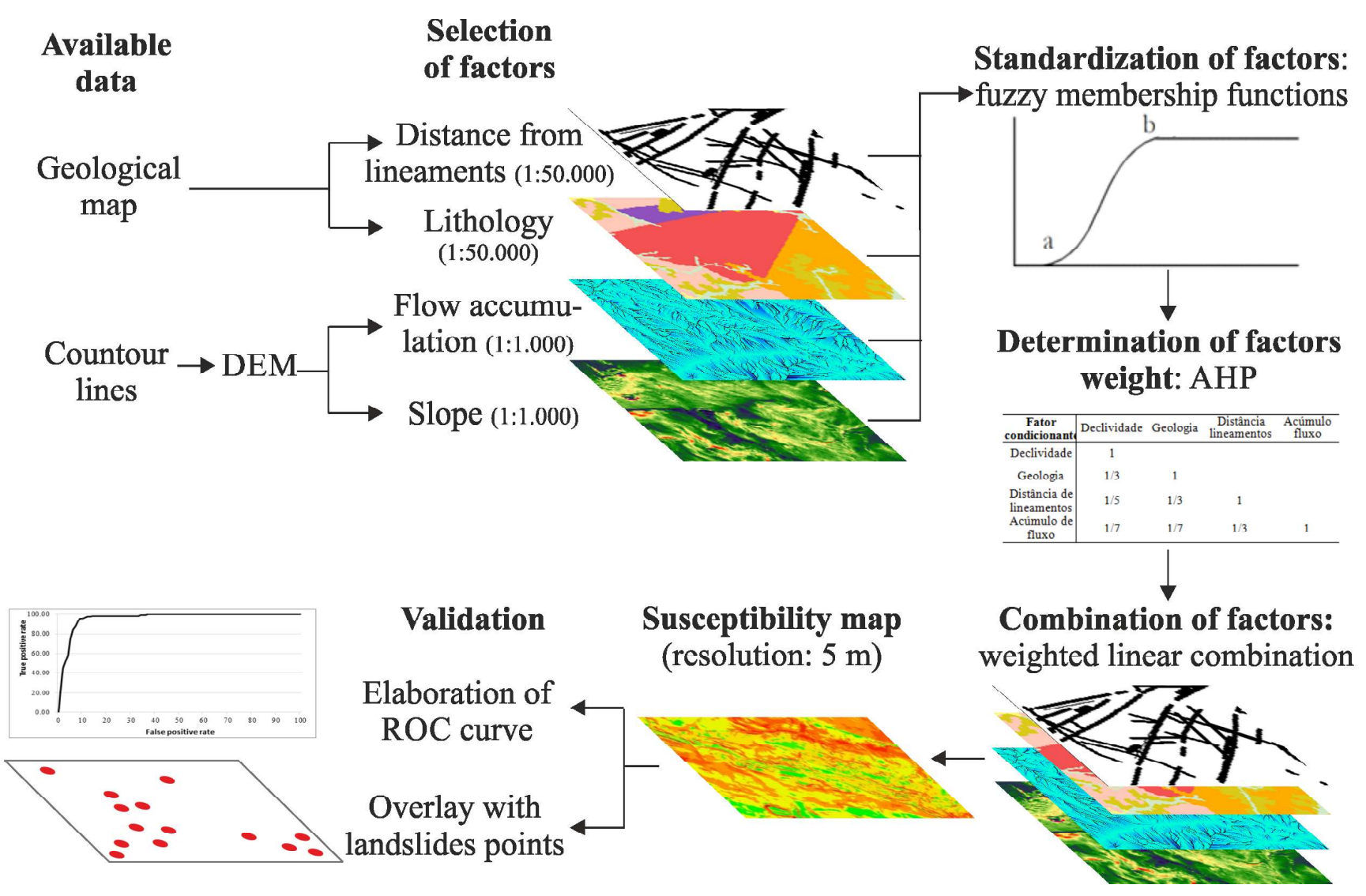

Figure 3 - Flow chart for landslide susceptibility assessment in Porto Alegre municipality.

A landslide inventory was compiled through the interpretation of field survey reports from 2007 to 2013 of the Porto Alegre Risk Areas Program (Programa de Áreas de Risco de Porto Alegre - PAR). These reports are elaborated based on detailed field surveys after the occurrence of landslides. Totally, 107 shallow translational and rotational landslides were mapped. The inventory results, as well as a detailed analysis of instability patterns in Porto Alegre municipality, are fully described by Brito et al. (2016). Despite the significant number of records, it should be noted that only the events that caused damage to society and occurred in urbanized areas were recorded by PAR. Thus, it does not represent all landslides occurring in the study area. Nevertheless, even having some shortcomings, the inventory provides an important data set, valuable both for guiding the susceptibility assessment process as well as for validating the results. It is worth mentioning that due to the reduced dimensions of the landslides in Porto Alegre and since they usually occur in densely populated areas, it is usually not possible to identify these features based on medium resolution satellite data. As highlighted by Brito (2015), only scars bigger than $300 \mathrm{~m}$ can be identified using Landsat data.

\subsection{Landslides conditioning factors}

The landslide conditioning factors (Figure 4) have been selected with the support of five academic researchers and three practitioners from various government departments, who have significant expertise in the field of landslide mapping in Porto Alegre. The availability, sensitivity, and independence of each factor were evaluated, aiming to create a susceptibility model as compact and robust as possible (Quan and Lee, 2012). Additionally, the recommendations of Van Westen et al. (2008), regarding the adequacy of each factor to the scale of work, were taken into account. In the end, factors chosen to be incorporated in the analysis and their respective relation with landslide susceptibility in the study area were as follows:

- Slope: is the main factor for stability analysis. As the slope gradient increases, the shear stress in soil and the vertical component of gravity increase as well, and, consequently, the higher is the probability of landslide occurrence (Lee and Min, 2001; Yalcin, 2008);

- Flow accumulation: has a direct relationship with surface and groundwater flow concentration, and thus, with soil saturation (Montgomery et al. 1998; Fernandes et al. 2004). As the upslope catchment area increases, the soil 
tends to become saturated and the probability of landslides is likely to rise;

- Lithology: is considered to be one of the main decisive factors in landslide susceptibility assessment. The geologic basement affects the formation of soils with different cohesion, strength, texture and permeability and, hence, with distinct geotechnical behavior (Rozos et al. 2011);

- Distance from lineaments: fault and shear zones are preferential areas for rock mass weathering and, thereby, contribute to reduce the strength parameters of rocks and soil. In general, the smaller the distance from tectonic structures the higher is the probability of landslides occurrence (Foumelis et al. 2004; Pourghasemi et al. 2012). In this study, only the most prominent lineaments were considered due to data availability limitations. However,
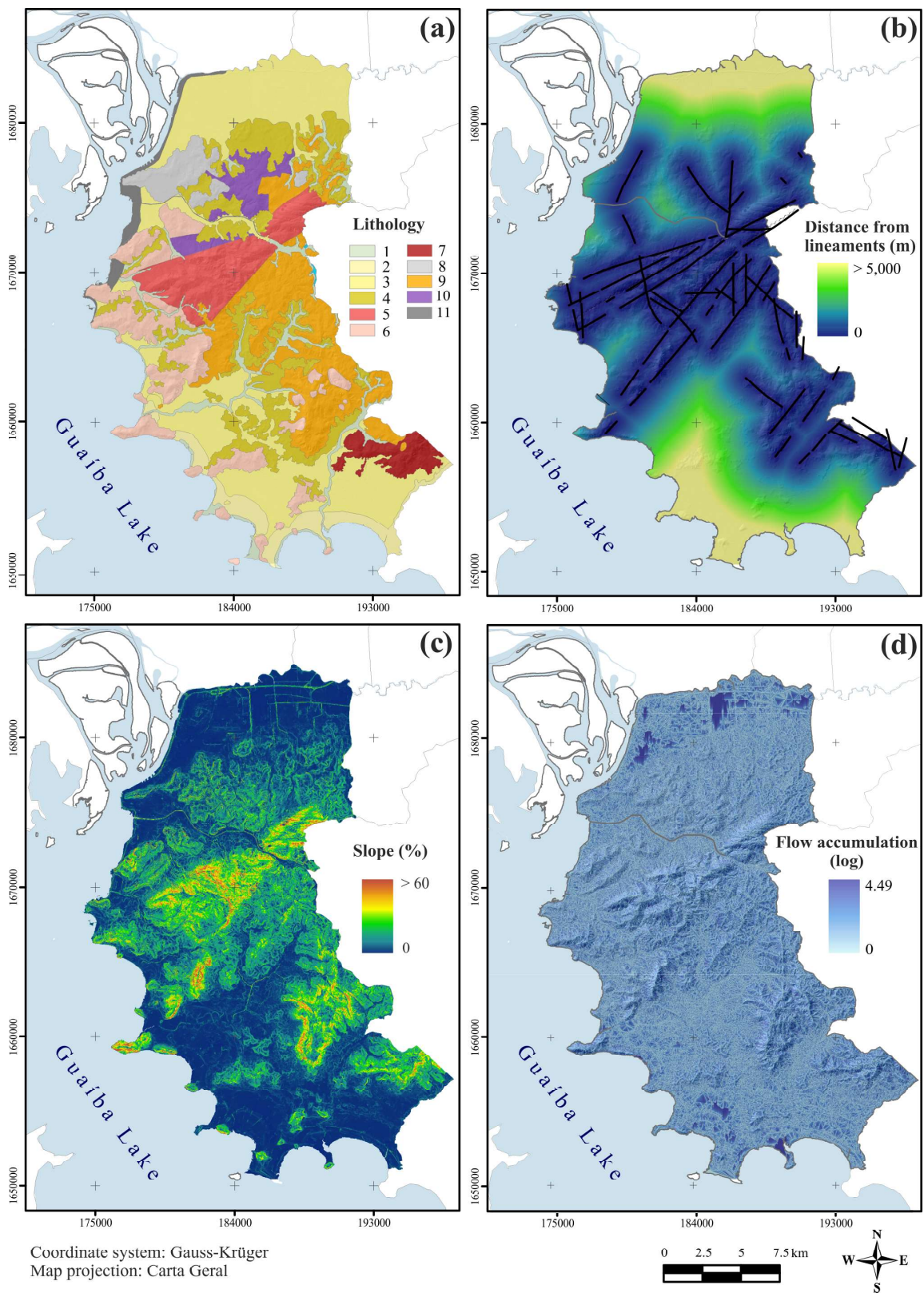

Figure 4 - Landslide conditioning factors

wherever possible detailed geological and lineament maps should be used.

It is important to highlight that factors such as the slope aspect and curvature were also considered in a preliminary analysis. Nevertheless, since no statistically significant correlations were found between these variables and the occurrence of landslides in Porto Alegre (Brito et al. 2017) they were not considered in the model described here. Likewise, the land use and the pedology were also evaluated, as fully described by Brito (2014). However, the inclusion of such variables did not affect the final results and did not increase the model accuracy. Hence, to keep the model as simple and robust as possible, we decided to consider only four conditioning factors in the final susceptibility scenario.

(d)

d) 


\subsection{Standardization of landslide conditioning factors}

To allow the combination of the different conditioning factors, standardization has to be applied. In this study, the original values were allocated in a continuous and dimensionless scale, ranging from 0 (no susceptibility) to 1 (full susceptibility), by means of fuzzy set membership functions (Zadeh 1965). Fuzzy sets are more realistic when compared to the classic boolean logic, since the standardization of data is done by considering a continuous scale, rather than a crisp binary set member-
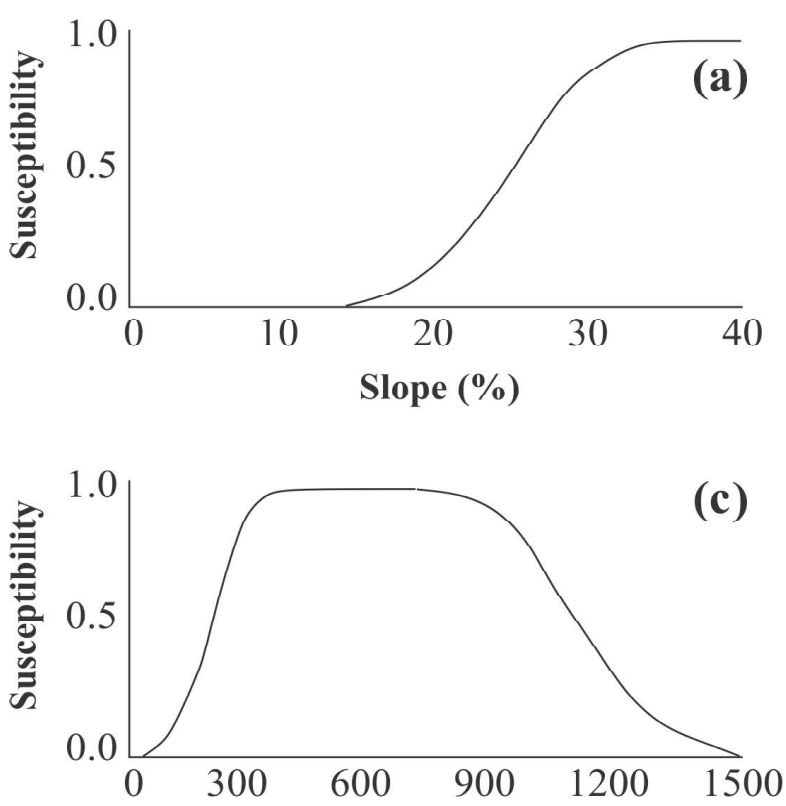

Flow accumulation $\left(\mathbf{m}^{2}\right)$ ship (Ghosh et al. 2012). Furthermore, they allow taking into account the uncertainty of human decision making, which is a key element in any susceptibility assessment. The control points and membership functions for each factor were defined based on its relative importance to landslide predisposition according to local experts and existing literature (Figure 5). In addition, the spatial relationship between conditioning factors and the 107 landslides mapped were used to check the consistency of the expert's judgments (Brito et al., 2016).
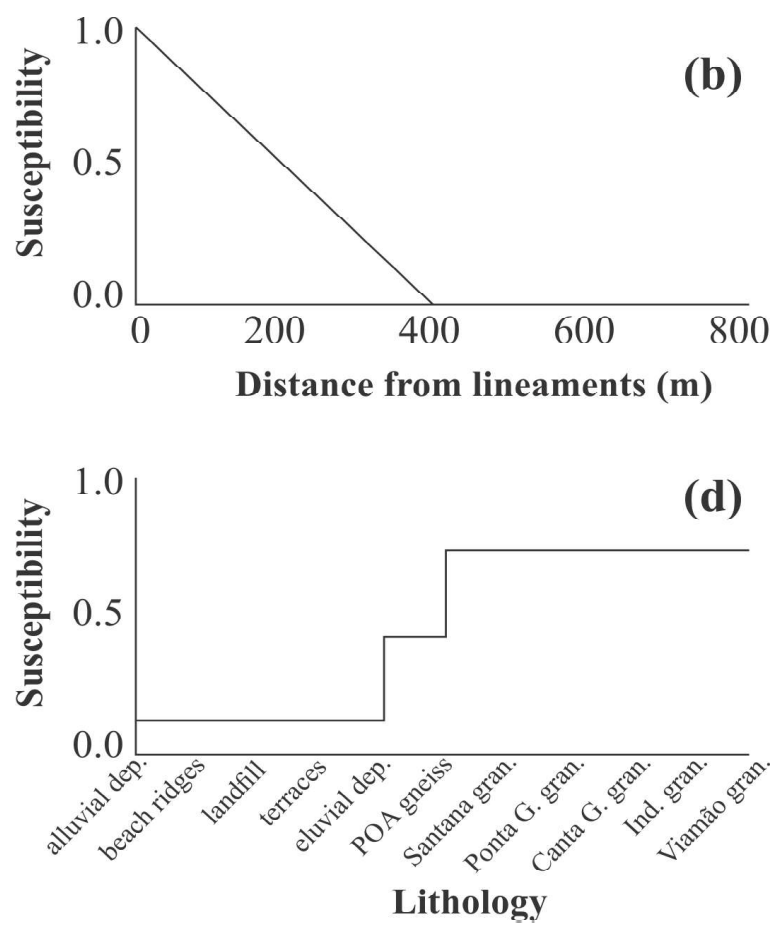

Figure 5 - Fuzzy membership functions and control points used in the standardization of landslide conditioning factors.

\subsection{Determination of landslide conditioning factors weights}

The relevance of each factor for landslide predisposition was determined through the MCA Analytic Hierarchy Process (AHP), based on interviews with local experts. This MCA technique, developed by Saaty (1977), reduces complex decision problems into a sequence of pairwise comparisons, which can be easily understood. Because of its simplicity and flexibility, AHP has been widely applied in landslide susceptibility studies (e.g. Yalcin and Bulut 2007; Thanh and Smedt
2011; Park et al. 2012; Reis et al. 2012; Pourghasemi et al. 2012; Hasekioğulları and Ercanoglu 2012; Dragićević et al. 2015). In this technique, a reciprocal pairwise matrix is constructed by comparing the factors and assigning a relative importance value to its relation, according to a 9-point continuous scale (Figure 6). Once these comparisons are done, the factor weights are determined by the principal eigenvector of the matrix, as shown in Eq. (1). A detailed description on AHP can be found in Belton and Stewart (2002).

\begin{tabular}{|c|c|c|c|c|c|c|c|c|}
\hline $1 / 9$ & $1 / 7$ & $1 / 5$ & $1 / 3$ & 1 & 3 & 5 & 7 & 9 \\
\hline extremely & $\begin{array}{l}\text { very } \\
\text { strongly }\end{array}$ & strongly & moderately & equally & moderately & strongly & $\begin{array}{c}\text { very } \\
\text { strongly }\end{array}$ & extre \\
\hline ess i & $\operatorname{tant}$ & & & ually im & $r \tan t$ & & More & importan \\
\hline
\end{tabular}

Figure 6 - Scale of relative importance between factors pairs (Eastman 2009). 


$$
A w=\lambda_{\max }
$$

where $A$ is the pairwise comparison matrix; $w$ is the vector of weights; and $\lambda_{\text {max }}$ is the maximum eigenvalue of the matrix.

One of the AHP's strengths is to provide ways to evaluate the inconsistency of the expert's judgments by means of a consistency ratio (CR), which measures the probability that the matrix ratings were randomly generated. ACR of 0.1 or less indicates that the judgments have an acceptable level of consistency, and the weights are valid. Otherwise, if CR is higher than 0.1, there are inconsistencies in the evaluation process and the matrix should be revised (Saaty 1980). For this study, the CR was found to be 0.05 , which indicates that consistent judgments were used. This was expected since the knowledge from experienced geologists, geomorphologists, and geotechnical engineers was taken into account. The final weights are shown in Table 1. Slope received the highest weight (0.5581), with similar values to those adopted by Ayalew et al. (2004), Abella and Van Westen (2007), Reis et al. (2012), Günther (2012). Lithology was assigned as the second most important (0.2789) (e.g. Zhou et al. 2006; Akgün and Bulut 2007; Kamp et al. 2008), followed by distance from lineaments (0.1130) (e.g. Intarawichian and Dasananda 2010; Suh et al. 2011; Rozos et al. 2011; Teimouri and Graee 2012), and, finally, by flow accumulation (0.0501) (e.g. Ghosh et al. 2011; Mondal and Maiti 2012).

Table 1: Pairwise comparison matrix, conditioning factors weights and consistency ratio.

\begin{tabular}{l|c|c|c|c|c}
\hline Conditioning factor & Slope & Lithology & $\begin{array}{c}\text { Distance from } \\
\text { lineaments }\end{array}$ & Flow & Weight \\
\hline Slope gradient & 1 & & & & 0.5581 \\
Lithology & $1 / 3$ & 1 & & & 0.2789 \\
Distance from & $1 / 5$ & $1 / 3$ & 1 & & 0.1130 \\
lineaments & $1 / 7$ & $1 / 7$ & $1 / 3$ & 1 & 0.0501 \\
Flow accumulation & \multicolumn{7}{l}{} \\
\hline
\end{tabular}

\subsection{Combination of landslide conditioning factors}

Once the weights were established, a weighted linear combination (WLC) was employed to integrate the fuzzified factors on a domain level. Due to its straightforwardness, WLC is probably the best known and most widely applied GIS aggregation method (e.g. Gorsevski et al. 2006; Yalcin and Bullut 2007; Feizizadeh and Blaschke 2013; Kouli et al. 2014; Dragićević et al. 2015). This approach is based on the concept of a weighted average, where each standardized factor is multiplied by its weight, as shown in Eq. (2).

$$
\begin{gathered}
S=f_{\text {slope }} * w_{A H P}+f_{\text {litol. }} * w_{A H P}+f_{\text {dist.lineaments }} * \\
w_{A H P}+f_{\text {flowacc. }} * w_{A H P}
\end{gathered}
$$

where $\mathrm{S}$ represents the final score of susceptibility; is the standardized factors; is the factor weights obtained by the AHP technique.
This equation was performed pixel by pixel, resulting in a continuous landslide susceptibility map, with values ranging from 0.00 to 0.91 . In order to facilitate its interpretation, the map was divided into five susceptibility classes, by using methods such as quantiles, natural breaks, and equal intervals. The quantiles approach placed widely different values into the same class (Ayalew and Yamagishi 2005) while the natural break emphasized the very high susceptibility class relative to others. Thus, the equal interval method was chosen as the most appropriate function for the study area (e.g. Dai et al. 2001; Kanungo et al. 2006; Akgun and Türk 2010; Dragićević et al. 2015). In the end, the following susceptibility classes were obtained: very low (interval 0.00 to 0.18 ), low ( 0.18 to 0.36 ), moderate ( 0.36 to 0.54 ), high ( 0.54 to 0.73$)$, and very high $(0.73$ a 0.91$)$.

\subsection{Validation of the landslide susceptibility map}

Validation is an essential step in the development of any susceptibility assessment as it allows determining 


\section{Multi-Criteria Analysis Applied to Landslide Susceptibility Mapping}

the predictive capacity of the model so that it can be applied with confidence. In this study, the validation was performed by comparing the susceptibility map with the 107 known landslides points, by using simple overlay. Furthermore, the degree of fit of the obtained map was verified through the analysis of the ROC curve (e.g. Poiraud 2014). This method allows assessing the overall accuracy of a model in a continuous way, avoiding errors due to the map division into susceptibility classes. ROC curves plot the proportion of areas with landslides correctly classified as susceptible (true positive rate) against the proportion of stable terrain units classified as susceptible (false positive rate) (Frattini et al 2010). From this operation, the area under the curve (AUC) with the defined threshold (selected as 100 in this study) was determined, assessing the performance of the model on a scale ranging from 0 to 1 , where 1 corresponds to a perfect model and values below 0.5 represent a random prediction (Hasekioğullari and Ercanoglu 2012).

\section{Results and discussion}

The results show that the largest proportion of the study area was mapped as belonging to very low susceptibility class, whose surface comprises $52.2 \%$ of the total area (Figure 7). The average slope is 5\%, which inhibits the flow of soil and rocks. The substrate is composed predominantly by sediments. Given these characteristics, the natural occurrence of landslides is very unlikely in these places. Nevertheless, this class is often affected by floods as reported by CPRM (2015).

A total of $124.9 \mathrm{~km}^{2}$ or $26.2 \%$ of the area was mapped as being with low susceptibility. The slope in this class varies between 6 and $15 \%$ and the geology is represented basically by the Viamão and Ponta Grossa granites. Even though landslides are unlikely to occur in this class, the incidence of such processes cannot be disregarded. As mentioned by Remondo et al. (2005) even in places where natural factors do not favor the occurrence of landslides, these processes can be triggered by human intervention.

Sites mapped as moderate amounted to only $3.9 \%$ of the study area. They are covered basically by sedimentary deposits, with slopes ranging mainly between 20 and $25 \%$. Though the natural factors are not favorable to landslides in this class, such processes should not be disregarded since they can be unleashed by wrong hu- man intervention. For this reason, the urbanization of these areas should be preceded by local analysis to check whether the site can be occupied without restriction or requires the implementation of risk mitigation measures.

High and very high susceptible zones comprise respectively $3.1 \%$ and $5.1 \%$ of the municipality. They are concentrated on hillsides with extremely fractured igneous rocks, a large density of faults and with slopes higher than $30 \%$. Hence, the occupation of these sites is not recommended due to the costs associated with the implementation of risk reduction measures. Despite that, approximately $8.3 \mathrm{~km}^{2}$ of these two classes are already urbanized (Table 2), a situation that tends to worsen since urban sprawl is inevitable and continuous. Therefore, these areas should be closely monitored in order to prevent new occupation, as well as be prioritized for carrying out detailed landslide hazard and risk assessment studies.

As it can be seen in Table 2, there is no scarcity of suitable areas for new urban developments. Hence, public authorities have enough leeway to guide urban expansion to safe places, seeking for a more sustainable and secure future. Nevertheless, Dias (2014) highlighted that during the last 20 years, a significant increase in population occurred in the Porto Alegre Ridge, precisely a region that presents mainly high or very high susceptibility. The urban growth in these inappropriate sites accentuates the changes in surface processes, altering infiltration and runoff patterns, which in turn may induce the occurrence of landslides. According to the PAR reports this is usually the case in Porto Alegre, where human actions are considered to be the major landslide triggering factor.

Since absolute measurements of landslide susceptibility are not feasible, two alternative validation procedures were applied. First, the simple overlay method showed that around $85 \%$ of the 107 landslides known locations fell within the very high susceptibility class while $10.28 \%$ lie into the high susceptibility category (Figure 8). In the moderate and low classes, the percentage of landslides events was reduced, with only $2.80 \%$ and $1.87 \%$ of all landslides, respectively. Furthermore, no landslides were observed in the very low class. This indicates that the landslide susceptibility map is reliable, and the set of factors and weights used was adequate. Thus, is possible to assume that approximately $95 \%$ of future landslides in Porto Alegre are likely to occur in areas mapped with high and very high susceptibility, which cover only $39.40 \mathrm{~km}^{2}(8.2 \%)$ of the study area. 


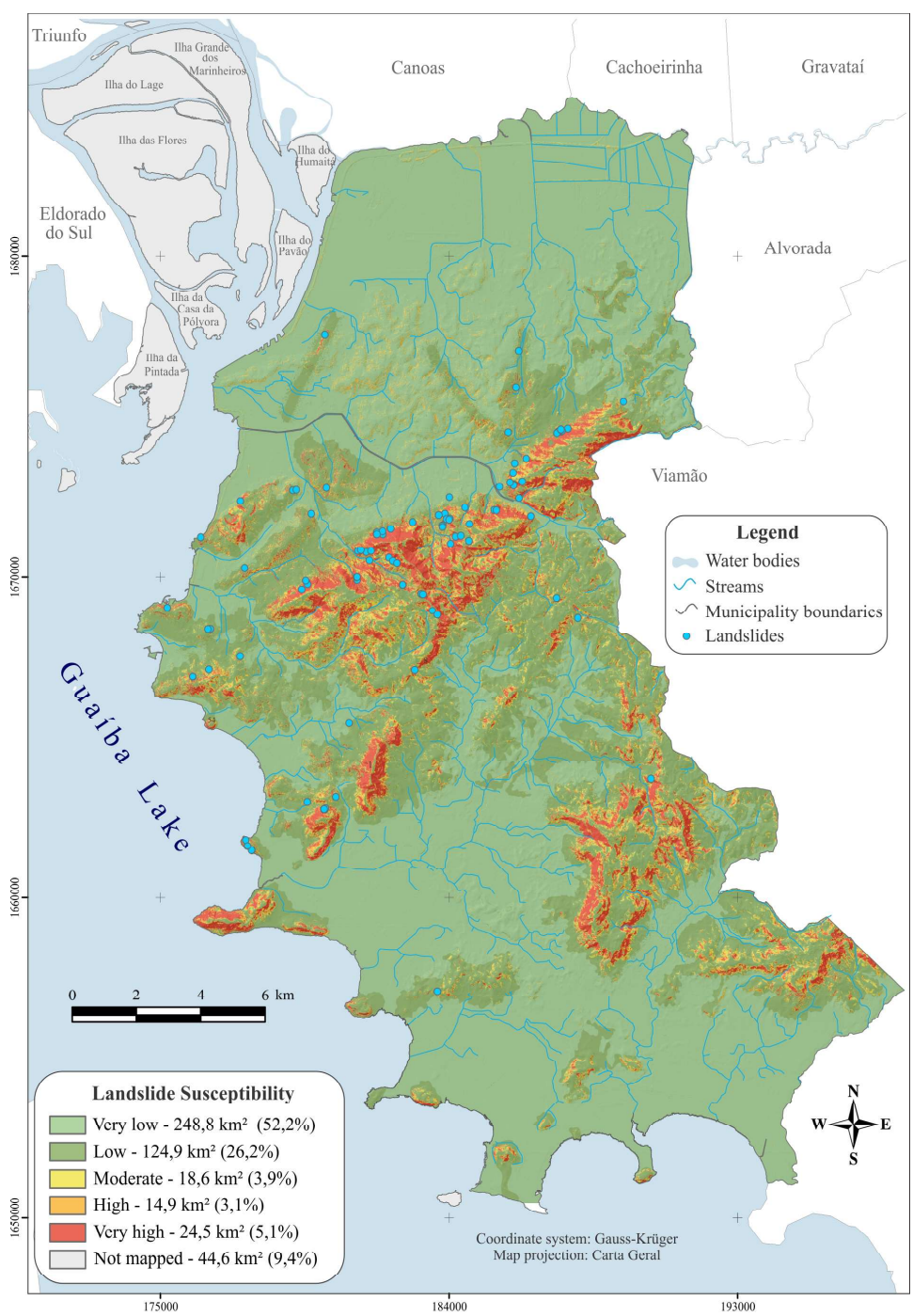

Figure 7 - Landslide susceptibility map for Porto Alegre municipality and the location of 107 landslides occurrences.

Table 2: Distribution of the area and percentage of urbanized and non-urbanized areas according to each susceptibility class

\begin{tabular}{c|c|c|c|c}
\hline Susceptibility class & Area $\left.\mathbf{( k m}^{\mathbf{2}}\right)$ & Area (\%) & Urbanized (\%) & $\begin{array}{c}\text { Non-urbanized } \\
\mathbf{( \% )}\end{array}$ \\
\hline Very low & 248.8 & 52.2 & 45.86 & 54.14 \\
Low & 124.9 & 26.2 & 38.43 & 61.57 \\
Moderate & 18.6 & 3.9 & 28.18 & 71.82 \\
High & 14.9 & 3.1 & 29.32 & 70.68 \\
Very high & 24.5 & 5.1 & 16.27 & 83.73 \\
Not mapped (islands) & 44.6 & 9.4 & 6.85 & 93.15 \\
\hline
\end{tabular}

The five landslides that fell in the low and moderate susceptibility classes do not represent necessarily disagreements. An inspection of the PAR field reports revealed that wrong human intervention was the main cause of landslides in all cases. They were not only triggered by natural factors, but mainly by human activities such as the inappropriate construction of retaining walls, modification of the slope profile by cut-and-fills, and disposal of wastewater directly into the surface.

Predicting the effects of anthropogenic activities on the slope stability is far more difficult than predicting the susceptibility on natural slopes (Preuth et al. 2010). 


\section{Multi-Criteria Analysis Applied to Landslide Susceptibility Mapping}

Hence, additional factors should be considered, and field surveys should be done. In this sense, Zhao et al. (2010) propose a human impact index that provides an estimate of the contribution of anthropogenic activities on landslide processes by incorporating variables such as buildings and road densities. In addition, indicators like population density, constructive type and degree of urban consolidation could be used (Remondo et al. 2005). According to the author, the consideration of those indicators can increase significantly the performance of susceptibility assessments in urbanized areas. In this study, a layer with the land use, including formal and informal settlements, was used to predict such effects. Nevertheless, due to scale limitations (1:15.000), the consideration of this factor did not increase the model accuracy. In fact, the prediction rate was worse (see Brito, 2014).

The second assessment of the model outputs is given by the ROC curve (Figure 9). The higher the percentage of the area under the curve, the greater is the model's accuracy (Kamp et al. 2008). The AUC was found to be 0.960 , which means that the susceptibility map is robust and has an acceptable performance since it allows predicting most of the known landslides in a small area. As an example, the $5 \%$ most susceptible area comprises approximately $75 \%$ of the total landslides points.

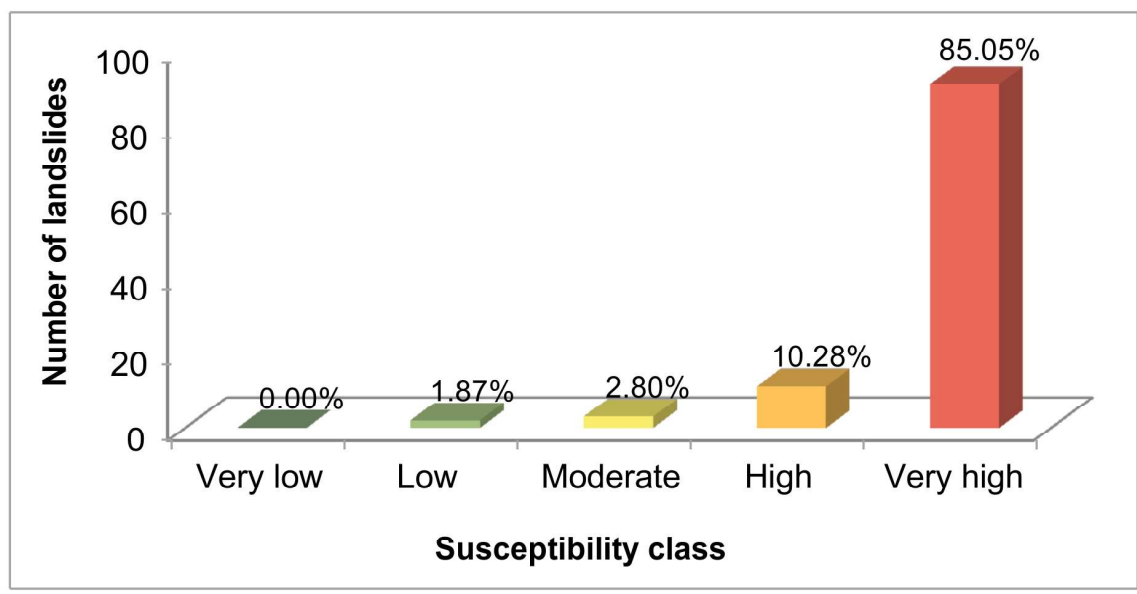

Figure 8 - Percentage of 107 known landslide occurrences within each landslide susceptibility class for Porto Alegre municipality.

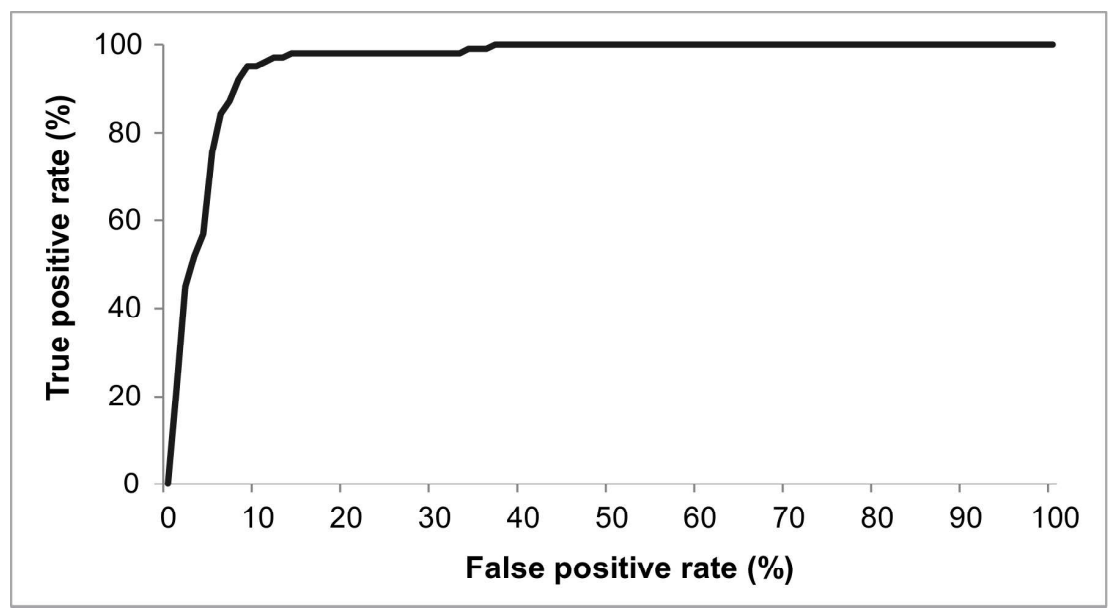

Figure 9 - ROC curve of the landslide susceptibility map.

When compared to the results achieved in similar studies, the AUC value obtained for Porto Alegre can be considered high (e.g. Suh et al. 2011; Akgün 2012; Poudyal 2012; Guillard and Zêzere, 2012). It is believed that the high AUC value obtained is mainly due to the support of local experts in all steps of the study, accompanied by a careful analysis of the set of criteria. This allowed a reliable evaluation of the conditioning factors and a proper interpretation of their relationships with landslide susceptibility in the study area. Moreover, 
the use of fuzzy membership functions prevented that the data were grouped into classes with crisp limits, retaining their full and more realistic continuous variation (Schicker and Moon 2012). On the other hand, the characteristics of the landslides that occurred in Porto Alegre also influenced the validation results, as they are located mostly at the Porto Alegre Ridge and, therefore, it was possible to reach most of the landslides in a smaller area.

It is worth noting that, as occurs with any other methodology, limitations and inherent uncertainties exist. One of the main drawbacks of this study refers to the fact that only past landslides were used to validate the model. Thus, it is not possible to determine the ability of the model to predict future landslides, which is essential for practical purposes. Therefore, further research is needed to address this issue. The classification of the susceptibility map into five classes is another source of errors. Different methods of class division can result in significant variances in the final maps, which can be completely distinct (Garcia et al. 2007). In this sense, Feizizadeh and Blaschke (2013) point out that the limits between classes of susceptibility are not clear, and, therefore, subject to ambiguity. Major problems are observed, especially when considering the values near to the limit of each class, for example, values between high and very high susceptibility classes. Thus, it is important to consider the statistical assumptions underlying the classification process (Kritikos and Davies 2011). The equal interval method, used in this study, divides the range of values into equally sized sub-ranges. It seemed adequate for the study area since the landslides occurred mainly in the higher susceptibility class.

Despite the above-mentioned shortcomings, the approach presented here provides a flexible method for landslide susceptibility assessment in urban areas and shows an improvement when compared to previous studies done in Porto Alegre municipality (e.g. Reckziegel 2012; CPRM 2015). A visual comparison of the results obtained by Reckziegel (2012) and by CPRM (2015) indicates that the areas with higher susceptibility are the same as those identified in this study. This was expected as both studies considered the slope as the main conditioning factor. Nevertheless, this study has the advantage of considering intermediate susceptibility levels. Reckziegel (2012), for example, used a Boolean approach and generated a map with only two classes, namely susceptible and not susceptible. Although it was a pioneering work, its binary character limits the practical use since it does not admit intermediate susceptibility degrees, where the criteria outweigh others. In this sense, WLC is advantageous as it allows ranking the susceptibility values continuously, so that different sites can be assessed on how dangerous one is in relation to each other. Such a result provides better subsidies for territorial planning as it makes possible selecting priorities. Furthermore, using AHP to compute weights makes value judgment explicit and transparent (Belton and Steward 2002), what facilitates its understanding by a broader public.

Considering the spread of web-based GIS tools, this opens the concrete possibility of citizens to directly give inputs on decision processes for urban development, foreseeing community-based decision support systems as already exist in some cities (e.g. Nagasaka 2006). In the same way, the conditioning factors can be modified at any time once additional data become available, and their weights and notes may be recomputed, allowing the generation of scenarios for different mass movement types (e.g. specific maps for rotational, planar landslides and rockfalls) as well as for different purposes (e.g. Civil Defense, urban planning, etc.).

\section{Conclusions}

Due to the lack of geotechnical data as well as comprehensive landslide inventories, landslide susceptibility assessments covering entire municipalities or regions are normally not carried out in Brazil. In this paper, we proposed a MCA expert-based method for assessing landslide susceptibility in urban areas while considering the data availability and the weights uncertainties through the use of fuzzy logic. Results demonstrated that it is possible to produce reliable maps through the use of GIS tools, employing only available data. The advantages of this approach in contrast to deterministic and physically based models consist in ease of update, cost-effectiveness, and reproducibility of the results. Nevertheless, it should be noted that, even though the model employed produced meaningful results, MCA approaches strongly depend on evaluator's subjective preferences.

From a practical standpoint, the results obtained may support local authorities to identify conflict situations between slope dynamic and human occupation as well as to monitor high susceptibility areas, in order to 
avoid new urban settlements. Additionally, the susceptibility map can be used to identify places for site-specific risk assessment, enabling to prioritize human, technological and financial resources and, thereby, improving hazard mitigation. It is believed that similar studies can be developed in other municipalities as an early-stage assessment of the landslide risk.

\section{Acknowledgments:}

The present work was supported by the National Research Council of Brazil (CNPq) through the Grant $\mathrm{N}^{\mathrm{o}} 131160 / 2012-5$. The authors are thankful to the Brazilian Geological Survey (CPRM) and the Porto Alegre Risk Areas Program (PAR-SMAM).

\section{References}

ABELLA, E. A. C.; VAN WESTEN, C. J. Generation of a landslide risk index map for Cuba using spatial multi-criteria evaluation. Landslides, v. 4, n. 4, p.311-325, 2007.

ALEOTTI, P.; CHOWDHURY, R. Landslide hazard assessment: summary review and new perspectives. Bulletin of Engineering Geology and the Environment, v. 58, n. 1, p. 21-44, 1999.

AKGÜN. A comparison of landslide susceptibility maps produced by logistic regression, multi-criteria decision, and likelihood ratio methods: a case study at İzmir, Turkey. Landslides, v. 9, n. 1, p. 93-106, 2012.

AKGÜN, A.; BULUT, F. GIS-based landslide susceptibility for Arsin-Yomra (Trabzon, North Turkey) region. Environmental Geology, v. 51, n. 8, p. 1377-1387, 2007.

AKGÜN, A.; TÜRK, N. Landslide susceptibility mapping for Ayvalik (Western Turkey) and its vicinity by multicriteria decision analysis. Environmental Earth Sciences, v. 61, n. 3, p. 595-611, 2010.

AYALEW, L.; YAMAGISHI, H. The application of GIS-based logistic regression for landslide susceptibility mapping in the Kakuda-Yahiko Mountains, Central Japan. Geomorphology, v. 65 , n. 1-2, p. 15-31, 2005.

AYALEW, L.; YAMAGISHI, H.; UGAWA, N. Landslide susceptibility mapping using GIS-based weighted linear combination, the case in Tsugawa area of Agano River, Niigata Prefecture, Japan. Landslides, v. 1, n. 1, p.73-81, 2004.

BARREDO, J. I.; BENAVIDES, A.; HERVÁS, J.; VAN WESTEN, C. J. Comparing heuristic landslide hazard assessment techniques using GIS in the Tirajana basin, Gran Canaria Island, Spain. International Journal of Applied Earth Observation and Geoinformation, v. 2, n. 1, p. 9-23, 2000.

BELTON, V.; STEWART, T. Multiple criteria decision analysis: an integrated approach. Kluwer Academic Publishers, Boston, 2002 .

BORTOLOTI, F. D.; CASTRO JUNIOR, R. M.; ARAÚJO, L. C.; MORAIS, M. G. Preliminary landslide susceptibility zonation using GIS-based fuzzy logic in Vitória, Brazil. Environmental Earth Sciences (Online), 2015.

BRITO, M.M. Geoprocessamento aplicado ao mapeamento da suscetibilidade a escorregamentos no município de Porto Alegre, RS. 168 f. Dissertacao (Mestrado em Engenharia Civil) Universidade Federal do Rio Grande do Sul. Porto Alegre, 2014.

BRITO, M.M. Identification of landslides scars in the Eastern Edge of the Paraná Basin based on Landsat 5-tm images. Revista Brasileira de Geografia Física, v. 8, n. 1, p. 56-70, 2015.

BRITO, M. M.; WEBER, E. J.; KRIGGER, V. S.; LEITZKE, F. P. Analysis of landslide conditioning factors in Porto Alegre municipality based on historical data. Brazilian Journal of Cartography, v. 68, n. 9, p. 1853-1872, 2016.

CARRARA, A.; GUZZETTI, F. Use of GIS technology in the prediction and monitoring of landslide hazard. Natural Hazards, v. 20, p. 117-135, 1999.

CPRM, Serviço Geológico do Brasil. Carta de suscetibilidade a movimentos gravitacionais de massa e inundação: município de Porto Alegre - RS. Escala 1:70.000. Disponível em: <http:// rigeo.cprm.gov.br/xmlui/bitstream/handle/doc/15106/CSPortoAlegre.pdf?sequence=1>. Acesso em: 20 Maio 2017. CPRM, 2015.

DAI, F. C.; LEE, C. F.; ZHANG, X. H. GIS-based geoenvironmental evaluation or urban land-use planning: a case study. Engineering Geology, v. 61, n. 4, p. 257-271, 2001.

DI MARTIRE, D.; DE ROSA, M.; PESCE, V.; SANTANGELO, M. A.; CALCATERRA, D. Landslide hazard and land management in high-density urban areas of Campania region, Italy. Natural Hazards and Earth System Sciences, v. 12, n. 4, p. 905-926, 2012.

DIAS, T. S. Análise das intervenções na morfologia original e na dinâmica geomorfológica em áreas alagáveis do município de Porto Alegre - RS. 170 pp. Master thesis. UFRGS, Porto Alegre, 2014.

DRAGIĆEVIĆ, S.; LAI, T.; BALRAM, S. GIS-based multicriteria evaluation with multiscale analysis to characterize 
urban landslide susceptibility in data-scarce environments. Habitat International, v. 45, p. 114-125, 2015.

EASTMAN, J. R. Idrisi Taiga: Guide to GIS and image processing. Worcester: Clark Labs, 2009. 325 p.

FEIZIZADEH, B.; BLASCHKE, T. GIS-multicriteria decision analysis for landslide susceptibility mapping: comparing three methods for the Urmia lake basin, Iran. Natural Hazards, v. 65, n. 3, p. 2105-2128, 2013.

FEIZIZADEH, N.; BLASCHKE, T.; NAZMFAR, H.; MOGHADDAM, M. H. R. Landslide susceptibility mapping for the Urmia Lake basin, Iran: a multi-criteria evaluation approach using GIS. International Journal of Environmental Research, v. 7, n. 2, p. 319-336, 2013.

FEIZIZADEH, B.; JANKOWSKI, P.; BLASCHKE, T. A GIS based spatially-explicit sensitivity and uncertainty analysis approach for multi-criteria decision analysis. Computer \& Geosciences, v. 64, p. 81-95, 2014.

FELL, R.; COROMINAS, J.; BONNARD, C. CASCINI, L.; LEROI, E.; SAVAGE, W. Z. Joint Technical Committee on landslides and engineered slopes, JTC-1. Guidelines for landslide susceptibility, hazard and risk zoning for land-use planning. Engineering Geology, v. 102, n. 3-4, p. 83-111, 2008.

FERNANDES, N. F.; GUIMARAES, R. F.; GOMES, R. A. T.; VIEIRA, B. C.; MONTGOMERY, D. R.; GREENBERG, H. Topographic controls of landslides in Rio de Janeiro: field evidence and modeling. CATENA, v. 55, n. 2, p. 163-181, 2004.

FOUMELIS, M.; LEKKAS, E.; PARCHARIDIS, I. Landslide susceptibility mapping by GIS-based qualitative weighting procedure in Corinth area. Bulletin of the Geological Society of Greece, v. 36, p. 904-912, 2004.

FRATTINI, P.; CROSTA, G.; CARRARA, A. Techniques for evaluating the performance of landslide susceptibility models. Engineering Geology, v. 111, n. 1-4, p. 62-72, 2010.

GARCIA, R.; ZÊZERE, J. L.; OLIVEIRA, S. A importância do processo de classificação de dados na cartografia: um exemplo na cartografia de susceptibilidade a movimentos de vertente. Publicações da Associação Portuguesa de Geomorfólogos, v. 5 , p. $265-279,2007$.

GHOSH, J. K.; BHATTACHARYA, D. N.; SHARMA, S. K. Fuzzy knowledge based GIS for zonation of landslide susceptibility. In: Banerjee S (ed.) Applications of chaos and nonlinear dynamics in science and engineering. Springer Berlin Heidelberg, v. 2, p 21-37, 2012.

GHOSH, S.; CARRANZA, E. J. M.; VAN WESTEN, C.
J.; JETTEN, V. G.; BHATTACHARYA, D. N. Selecting and weighting spatial predictors for empirical modeling of landslide susceptibility in the Darjeeling Himalayas (India). Geomorphology, v. 131, n. 1-2, p. 35-56, 2011.

GORSEVSKI, P. V.; JANKOWSKI, P. GESSLER, P. E. An heuristic approach for mapping landslide hazard by integrating fuzzy logic with analytic hierarchy process. Control and Cybernetics, v. 35, n. 1, p. 121-146, 2006.

GUILLARD, C.; ZÊZERE, J. L. Landslide susceptibility assessment and validation in the framework of municipal planning in Portugal: The case of Loures Municipalit. Environmental Management, v. 50, n. 4, p.721-735, 2012.

GÜNTHER, A.; REICHENBACH, P.; MALET, J. P.; VAN DEN EECKHAUT, M.; HERVÁS, J.; DASHWOOD, C.; GUZZETTI, F. Tier-based approaches for landslide susceptibility assessment in Europe. Landslides (Online), v. 10, n. 15, p. 529-546, 2012.

GÜNTHER, A.; VAN DEN EECKHUT, M.; MALET, J. P.; REICHENBACH, P.; HERVÁS, J. Climate-physiographically differentiated Pan-European landslide susceptibility assessment using spatial multi-criteria evaluation and transnational landslide information. Geomorphology, v. 224, p. 69-85, 2014.

GUZZETti, F., CARRARA, A., CARdinAli, M., REICHENBACH, P., 1999. Landslide evaluation: a review of current techniques and their application in a multi-scale study, Central Italy. Geomorphology 31, 181-216.

HASEKIOĞUlLARI, G. D.; ERCANOGLU, M. A new approach to use AHP in landslide susceptibility mapping: a case study at Yenice (Karabuk, NW Turkey). Natural Hazards, v. 63, n. 2, p. 1157-1179, 2012.

HASENACK, H.; WEBER, E.; LUCATELLI, L. M. L. (Orgs.). Base altimétrica vetorial continua do município de Porto Alegre-RS na escala 1:1.000 para uso em sistemas de informação geográfica. Porto Alegre: Universidade Federal do Rio Grande do Suk, Instituto de Biociências, Centro de Ecologia, 2010.

IBGE, Instituto Brasileiro de Geografia e Estatística. Cidades, [online]. Disponível em: $<$ http://cidades.ibge.gov.br/xtras/perfil. php?codmun=431490> Accesso em: 30 Maio 2017, 2016.

INMET, Instituto Nacional de Meteorologia. Precipitação Pluviométrica Mensal no Jardim Botânico. Porto Alegre, 2014. Disponível em: <www2.portoalegre.rs.gov.br/metroclima/ default.php?p_secao=16>. Acesso em: 13 jun. 2016.

INTARAWICHIAN, N.; DASANANDA, S. Analytical hierarchy process for landslide susceptibility mapping in lower Mae Chaem 
Watershed, northern Thayland. Suranaree Journal of Science and Technology, v. 17, n. 3, p. 277-292, 2010.

IPT, Instituto de Pesquisas Tecnológicas. Mortes por deslizamentos no Brasil. Banco de Acidentes. São Paulo: Instituto de Pesquisas Tecnológicas, 2014.

FUJIMOTO, N. S. V. M. Implicações ambientais na área metropolitana de Porto Alegre: um estudo geográfico com ênfase na geomorfologia urbana. GEOUSP - Espaço e Tempo, v. 12, p. 141-178, 2002.

KANUNGO D. P.; ARORA, M. K.; SARKAR, S.; GUPTA, R. P. A comparative study of conventional, ANN black box, fuzzy and combined neural and fuzzy weighting procedures for landslide susceptibility zonation in Darjeeling Himalayas. Engineering Geology, v. 85, p. 347-366, 2006.

KAMP, U.; GROWLEY, B. J.; KHATTAK, G. A.; OWEN, L. A.; GIS-based landslide susceptibility mapping for the 2005 Kashmir earthquake region. Geomorphology, v. 101, n. 4, p. 533-543, 2008.

KOMAC, M. A landslide susceptibility model using the analytical hierarchy process method and multivariate statistics in perialpine Slovenia. Geomorphology, v. 74, n. 1-4, p. 1728,2006 .

KOULI, M.; LOUPASAKIS, C.; SOUPIOS, P.; ROZOS, D.; VALLIANATOS, F. Landslide susceptibility mapping by comparing the WLC and WofE multi-criteria methods in the West Crete Island, Greece. Environmental Earth Sciences, v. 72 , n. 12 , p. $5197-5219,, 2014$

KRITIKOS, T. R. H.; DAVIES, T. R. H. GIS-based MultiCriteria Decision Analysis for landslide susceptibility mapping at northern Evia, Greece. Zeitschrift der Deutschen Gesellschaft für Geowissenschaften, v. 162, n. 4, p. 421-434, 2011.

LEE, S.; MIN, K. Statistical analysis of landslide susceptibility at Yongin, Korea. Environmental Geology, v. 40, n. 9, p. 1095 $1113,2001$.

LISTO, F. L. R,; VIEIRA, B. C. Mapping of risk and susceptibility of shallow-landslide in the city of São Paulo, Brazil. Geomorphology, v. 169-170, n. 1, p. 30-44, 2012.

LIU, C. N.; WU, C. C. Mapping susceptibility of rainfalltriggered shallow landslides using a probabilistic approach. Environmental Geology, v. 55, n. 4, p. 907-915, 2008.

MACEDO, E. S.; CANIL, K.; SILVA, F. C.; MIRANDOLA, F. A.; GRAMANI, M. F.; OGURA, A. T.; CORSI, A. C.; SANTOS, L. P. Methodological procedures to landslide risk mapping in Brazilian slums. In: Margottini C, Canuti P, Sassa K (eds).
Landslide science and practice. Springer, Berlin Heidelberg, v. 6, p 399-403, 2013

MI - MINISTÉRIO DA INTEGRAÇÃO NACIONAL. Lista dos 821 municípios com o maior número de ocorrências de desastres naturais. Brasília, 2013. Disponível em: $<\mathrm{http}$ //www.integracao. gov.br/pt/c/document_library/get_file?uuid $=51 \mathrm{c} 80 \mathrm{bb} 2-9 \mathrm{bf} 9$ 4193-9eb2-1ba2cb2937e2\& groupId=10157>. Acesso em: 06 jun. 2016.

MICHEL, G. P.; KOBIYAMA, M.; GOERL, R. F. Comparative analysis of SHALSTAB and SINMAP for landslide susceptibility mapping in the Cunha River basin, southern Brazil. Journal of Soils and Sediments, v. 14, n. 7, p. 1266-1277, 2014.

MONDAL, S.; MAITI, R. Landslide susceptibility analysis of Shiv-Klola Watershed, Darjing: a remote sensing \& GIS based analytical hierarchy process (AHP). Journal of the Indian Society of Remote Sensing, v. 40, n. 3, p. 483-496, 2012.

MONTGOMERY, D. R.; SULLIVAN, K.; GREENBERG, H. M. Regional test of a model for shallow landslides. Hydrological Processes, v. 12, p. 943-955, 1998.

NAGASAKA, T. New mode of risk governance enhanced by an e-community platform. In: Ikeda S, Fukuzono T, Sato T (eds.) A better integrated management of disaster risks: toward resilient society to emerging disaster risks in mega-cities. TERRAPUB and NIED, p 89-107, 2006.

NERY, T. D.; VIEIRA, B. C. Susceptibility to shallow landslides in a drainage basin in the Serra do Mar, São Paulo, Brazil, predicted using the SINMAP mathematical model. Bulletin of Engineering Geology and the Environment, v. 74, n. 2, p. 369-378, 2015.

PARK, S.; CHOI, C.; KIM, B.; KIM, J. Landslide susceptibility mapping using frequency ratio, analytic hierarchy process, logistic regression, and artificial neural network methods at the Inje area, Korea. Environmental Earth Sciences, v. 68, n. 5, p. 1443-1464, 2012.

PASCARELLI, L.; LANÇONE, R.; COSTA, R.; PIRES, L.; MACEDO, E.; MIRANDOLA, F.; CHECCHINATO, F.; CANIL, K. Mapping geological at risk areas in the city of São Paulo: issues and results from the largest risk survey in Brazil. In: Margottini C, Canuti P, Sassa K (eds). Landslide science and practice. Springer Berlin Heidelberg, v. 6, p 349-355, 2013.

PHILIPP, R. P. Geologia. In: HASENACK, H; WEBER, E.; MACUZZO, S. (Orgs.). Diagnóstico Ambiental de Porto Alegre: geologia, solos, drenagem, vegetação/ocupação e paisagem. Porto Alegre: Secretaria Municipal do Meio Ambiente, 2008. cap. 1, p. 12-27. 
PHILIPP, R. P.; CAMPOS, R. S. de. Geologia, petrografia e litogeoquímica dos gnaisses Porto Alegre, RS, Brasil: Implicações geotectônicas. Revista Pesquisa em Geociências, v. 31, n. 2, p. 79-94, 2004.

POIRAUD, A. Landslide susceptibility-certainty mapping by a multi-method approach: a case study in the Tertiary basin of Puy-en-Velay (Massif central, France). Geomorphology, v. 216, p. 208-224, 2014.

POUDYAL, C. P. Landslide susceptibility analysis using decision tree method, Phidim, Eastern Nepal. Bulletin of the Department of Geology, Tribhuvan University, v. 15, p. 6976, 2012.

POURGHASEMI, H. R.; PRADHAN, B.; GOKCEOGLU, C. Application of fuzzy logic and analytical hierarchy process (AHP) to landslide susceptibility mapping at Haraz watershed, Iran. Natural Hazards, v. 63, n. 2, p. 965-996, 2012.

PREUTH, T.; GLADE, T.; DEMOUlin, A. Stability analysis of a human-influenced landslide in eastern Belgium. Geomorphology, v. 120, n. 1-2, p. 38-47, 2010.

QUAN, H. C.; LEE, B. G. GIS-Based landslide susceptibility mapping using analytic hierarchy process and artificial neural network in Jeju (Korea). KSCE Journal of Civil Engineering, v. 16, n. 7, p. 1258-1266, 2012.

RECKZIEGEL, B. W. Levantamento dos desastres desencadeados por eventos naturais adversos no estado do Rio Grande do Sul no período de 1980 a 2005. 2007. 259 f. Dissertação (Mestrado em Geografia) - Universidade Federal de Santa Maria, Santa Maria, 2007.

RECKZIEGEL, E. W. Identificação e mapeamento das áreas com perigo de movimento de massa no município de Porto Alegre, RS. 2012. 90 f. Dissertação (Mestrado em Geografia) Instituto de Geociências, Universidade Federal do Rio Grande do Sul, Porto Alegre, 2012.

RECKZIEGEL, E. W. Identificação e mapeamento das áreas com perigo de movimento de massa no município de Porto Alegre, RS. In: ROBAINA, L. E. S.; TRENTIN, R. (Orgs.). Desastres Naturais no Rio Grande do Sul. $1^{\text {a }}$ ed. Santa Maria: Editora UFSM, p. 360-376, 2013.

REIS, S.; YALCIN, A.; ATASOY, M.; NISANCI, R.; BAYRAK, T.; ERDURAN, M.; SANCAR, C.; EKERCIN, S. Remote sensing and GIS-based landslide susceptibility mapping using frequency ratio and analytical hierarchy methods in Rize province (NE Turkey). Environmental Earth Sciences, v. 66, n. 7, p. 2063-2073, 2012.
REMONDO, J.; SOTO, J.; DÍEZ, A. G.; TERÁN, J. R. D.; CENDRERO, A. Human impact on geomorphic processes and hazards in mountain areas in northern Spain. Geomorphology, v. 66, n. 1-4, p. 69-84, 2005.

ROZOS, D.; BATHRELlos, G. D.; SKILlODIMOU, H. D.; Comparison of the implementation of rock engineering system and analytic hierarchy process methods, upon landslide susceptibility mapping, using GIS: a case study from the Eastern Achaia County of Peloponnesus, Greece. Environmental Earth Sciences, v. 63, n. 1, p. 49-63, 2011.

RUFF, M.; CZURDA, K. Landslide susceptibility analysis with a heuristic approach in the Eastern Alps (Vorarlberg, Austria). Geomorphology, v. 94, n. 3-4, p. 314-324, 2008.

SAATY, T. L. A scaling method for priorities in hierarchical structures. Journal of Mathematical Psychology, v. 15, p. 234-281, 1977.

SAATY, T. L. The analytic hierarchy process. New York: McGraw-Hill, 1980. 287p.

SCHICKER, R.; MOON, V. Comparison of bivariate and multivariate statistical approaches in landslide susceptibility mapping at a regional scale. Geomorphology, v. 161-162, p. 40-57, 2012.

SOETERS, R.; VAN WESTEN, C. J. Slope stability: recognition, analysis and zonation. In: TURNER, A. K.; SCHUSTER, R. L. Landslides investigation and mitigation. Washington: Transportation Research Board, National Research Council Special Report, 247. cap. 8, 1996. p. 129-177.

SUH, J.; CHOI, Y.; ROH, T. D.; LEE, H. J.; PARK, H. D. National-scale assessment of landslide susceptibility to rank the vulnerability to failure of rock-cut slopes along expressways in Korea. Environmental Earth Sciences, v. 63, n. 3, p. 619632, 2011.

TEIMOURI, M.; GRAEE, P. Evaluation of AHP and frequency ratio methods in landslide hazard zoning (case study: Bojnord urban watershed, Iran). International Research Journal of Applied and Basic Sciences, v. 3, n. 9, p. 1978-1984, 2012.

THANH, L. N.; SMEDT, F. Application of an analytical hierarchical process approach for landslide susceptibility mapping in A Luoi district, Thua Thien Hue Province, Vietnam. Environmental Earth Sciences, v. 66, n. 7,p. 1739-1752, 2011.

UFSC Universidade Federal de Santa Catarina, CEPED Centro Estadual de Estudos e Pesquisas sobre desastres . Atlas brasileiro de desastres naturais 1991 a 2012: volume Brasil. CEPED, UFSC, Florianópolis, 2012. 
VAN WESTEN, C. J. The modelling of landslide hazards using GIS. Surveys in Geophysics, v. 21, n. 2-3, p. 241-255, 2000.

VAN WESTEN, C. J.; ABELLA, E. C.; KURIAKOSE, S. L. Spatial data for landslide susceptibility, hazard, and vulnerability assessment: an overview. Engineering Geology, v. 102, n. 3-4, p. 112-131, 2008.

WORLD BANK. Avaliação de perdas e danos: inundações e deslizamentos na região Serrana do Rio de Janeiro - Janeiro de 2011. TORO, J. (Coord.). Brasília: Banco Mundial; Governo do Estado do Rio de Janeiro, 2012. 59 p.

YALCIN, A. GIS-based landslide susceptibility mapping using analytical hierarchy process and bivariate statistics in Ardesen (Turkey): Comparisons of results and confirmations. CATENA, v. 72 , n. 1, p. 1-12, 2008 .

YALCIN, A.; BULUT, F. Landslide susceptibility mapping using GIS and digital photogrammetric techniques: a case study from Ardesen (NE-Turkey). Natural Hazards, v. 41, n. 1, p.
201-226, 2007.

ZADEH, L. A. Fuzzy sets. Information and Control, v. 8, p. 338-353, 1965.

ZHAO, W.; TIAN, Y.; WU, L.; LIU, Y. Human impact index in landslide susceptibility mapping. In: International Conference on Geoinformatics, 18., Beijing. Proceedings... Beijing: Peking University, 2010.

ZHOU, Q.; FENG, W.; SONG, S.; YUAN, L.; ZHOU, W. Remote sense and GIS-Based division of landslide hazard degree in Wanzhou district of the Three Gorges reservoir area. Wuhan University Journal of Natural Sciences, v. 11, n. 4, p. 780-786, 2006.

ZHU, A. B.; WANG, R.; QIAO, J.; QIN, C. Z.; CHEN, Y.; LIU, J.; DU, F.; LIN, Y.; ZHU, T. An expert knowledge-based approach to landslide susceptibility mapping using GIS and fuzzy logic. Geomorphology, v. 214, p. 128-138, 2014. 